\title{
PERANAN ASET KOMUNITAS DALAM PEMBERDAYAAN PEMUDA OLEH KOMUNITAS KAMPUNG MARKETER, KARANGMONCOL, PURBALINGGA
}

\author{
Suciati \\ STID Al-Hadid, Surabaya \\ suciati@stidalhadid.ac.id
}

\begin{abstract}
Abstrak: Studi ini dilatar belakangi adanya pemberdayaan yang sukses dilakukan komunitas Kampung Marketer kepada pemuda Desa Tamansari, Kecamatan Karangmoncol, Kabupaten Purbalingga. Dalam waktu tiga tahun berjalan, Kampung Marketer mengentaskan 748 pemuda dari urbanisasi yang disebabkan tidak adanya lapangan kerja di desa. Kampung Marketer mengubah pemuda desa hingga memiliki skill digital marketing, mendapatkan kerja bergaji tinggi, membuat rumah di desa menjadi kantor komersil untuk pusat pelatihan dan kantor. Kesuksesan tersebut tidak lepas dari dukungan aset komunitas seperti pemuda hingga warga desa lainnya. Peranan aset komunitas tersebut penting untuk dipahami karena menjadi modal dasar memberdayakan masyarakat. Studi ini, bertujuan untuk menguraikan peranan aset komunitas pada pemberdayaan pemuda desa oleh Kampung Marketer. Metodologi yang digunakan adalah riset kualitatif, teknik penggalian datanya wawancara pengurus, data berupa video wawancara yang diambil dari situs youtube.com, dan website Kampung Marketer. Hasilnya, peranan aset manusia yakni pemuda desa yang dijadikan objek pelatihan, sebelumnya tidak memiliki skill dan pekerjaan, menjadi memiliki skill digital marketing, bahkan mereka menjadi agen yang mengembangkan pemberdayaan komunitas Kampung Marketer. Aset fisik rumah warga diperankan sebagai tempat kegiatan pemberdayaan, rumah dapat menampung banyak aktivitas pelatihan dan kantor. Aset sosial karakter guyub masyarakat membuat penyebaran informasi kesuksesan kegiatan pemberdayaan ini ke masyarakat sehingga banyak yang meminta bergabung.

Kata kunci: Dakwah bil hal, Peranan aset komunitas, Kampung Marketer, Pemberdayaan Masyarakat, Pemuda Desa, Digital Marketing.
\end{abstract}

ROLES OF COMMUNITY ASSETS IN EMPOWERING VILLAGE YOUTH BY KAMPUNG MARKETER COMMUNITY, KARANGMONCOL, PURBALINGGA. Abstract: This study is grounded in an empowerment conducted by Kampung Marketer community to youth of Tamansari village, Karangmoncol, Purbalingga. Over 3 years, Kampung Marketer has solved 748 young people from urbanization due to the lack of jobs in their village. Kampung Marketer has changed those young people so that they have digital marketing skill, get highly earning work, and make village houses to be training centre and office. It cannot be separated from the support of community assets: the youth and other village people. Their roles are essential to understand because they become basic capital for empowering community. This study aims to explain roles of community assets in empowering the youth by Kampung Marketer. This qualitative research study uses videos of interviews as data taken from youtube.com and Kampung Marketer website. As a result, village young people, who previously had no skills and jobs, own digital marketing skill. Furthermore, they become agents developing Kampung Marketer's empowerment. Physical assets, such as people's houses, functions as places of empowerment. They accommodate many training and office activities. Social asset, such as a sense of communality, spreads the success of this empowerment to the society so that a lot of people want to join.

Keywords: Da'wah bil hal, roles of community assets, Kampung Marketer, Community Empowerment, Village Youth, Digital Marketing 


\section{Pendahuluan}

Artikel ini menjelaskan peranan aset komunitas yang dilakukan oleh Kampung Marketer dalam kegiatan pemberdayaan melalui pelatihan digital marketing untuk Pemuda Desa Tamansari, Kecamatan Karangmoncol, Kabupaten Purbalingga. Kegiatan pemberdayaan ini dapat mengentaskan masalah urbanisasi dan kemiskinan pemuda desa. Pemecahan masalah kemiskinan dengan membangun kesejahteraan masyarakat merupakan salah satu tujuan dakwah, salah satu tanggung jawab sebagai muslim. Dengan menyejahterakan masyarakat, maka akan memahami bagaimana prinsip Islam rahmatan lil alamin. Sebagaimana yang dijelaskan dalam surat Al Baqarah 177: "Bukanlah menghadapkan wajahmu ke arah timur dan barat itu suatu kebajikan, akan tetapi Sesungguhnya kebajikan itu ialah beriman kepada Allah, hari Kemudian, malaikat-malaikat, kitab-kitab, nabi-nabi dan memberikan harta yang dicintainya kepada kerabatnya, anak-anak yatim, orang-orang miskin, musafir (yang memerlukan pertolongan) dan orang-orang yang meminta-minta; dan (memerdekakan) hamba sahaya." ${ }^{1}$ Dari ayat tersebut Allah memberikan perintah kepada umat Islam untuk membantu orang miskin.

Dakwah membantu mengentaskan
kemiskinan memotivasi, mendorong, membangkitkan,

1. RI Departemen Agama, Al-Qur'an Terjemahan, Semarang: CV. Toha Putra, 1989, 43.

2 Mardan Mahmuda, "Dakwah Dan Pemberdayaan," Al-Hikmah: Jurnal Dakwah Dan Ilmu Komunikasi 7, no. 1 (2020): 9-20, https://ejournal.uinib.ac.id/jurnal/index.php/alhikma h/article/view/1470.

${ }^{3}$ Aliyudin, "Dakwah Bi Al-Hal Melalui Pemberdayaan Ekonomi Masyarakat," Anida Aktualisasi Nuansa IImu dan memberdayakan seluruh potensi yang ada di masyarakat untuk kehidupan yang lebih berdaya. ${ }^{2}$ Cara dakwah ini disebut dakwah bil hal. Dakwah dengan melakukan kegiatan mentransformasikan nilai-nilai Islam dalam bentuk kegiatan nyata untuk melakukan pengembangan dan pemberdayaan masyarakat yang meliputi manusia, ekonomi, dan lingkungan. Istilahnya adalah Tamkin. ${ }^{3}$ Rasulullah mencontohkan bagaimana melakukan dakwah bil hal, dengan memberikan bantuan secara nyata kepada orang miskin. "Dari Musa bin Anas, dari ayahnya (Anas r.a.) berkata: "Tidak pernah Rasulullah Saw. Dimintai sesuatu melainkan pasti ia memberikannya. Sungguh telah datang seorang peminta kepadanya, maka diberinya kambing yang berada di antara dua bukit, hingga ia kembali kepada kaumnya dan mengajak kaumnya: Hai kaumku segeralah kamu masuk Islam, karena Muhammad memberi seperti pemberian orang yang sama sekali tidak kuatir habis atau menjadi miskin". (HR Muslim No.2312). ${ }^{4}$

Pemberdayaan menjadi salah satu referensi dakwah bil hal kepada umat muslim. Hasil yang diharapkan adalah meningkatnya kesejahteraan masyarakat baik di dunia maupun akhirat. ${ }^{5}$ Pemberdayaan atau dikenal dengan istilah empowerment adalah salah satu solusi memecahkan masalah kemiskinan dengan menyejahterakan

Dakwah 15, no. 2 (2016): 187-206, https://doi.org/10.15575/anida.v15i2.

4 Akhmad Sagir, "Dakwah Bil-Hal: Prospek Dan Tantangan Da'i," Alhadharah Jurnal Ilmu Dakwah 14, no. 27 (2015): 15-27, doi: https://dx.doi.org/10.18592/alhadharah.v14i27.1224 5 Teguh Ansori, "Revitalisasi Dakwah Sebagai Paradigma Pemberdayaan Masyarakat," Jurnal Dakwah Dan Sosial 2, no. 1 (2019): 33-44, doi: https://doi.org/10.5281/zenodo.3544714 
masyarakat. Pemberdayaan adalah upaya mengubah perilaku masyarakat untuk mandiri dalam memenuhi semua aspek kehidupan seperti aspek ekonomi, pendidikan, spiritual, ataupun aspek sosial. ${ }^{6}$

Model pemberdayaan masyarakat banyak jenisnya. Salah satunya adalah kegiatan pengembangan sumber daya lokal. Misalnya mengajak masyarakat mengelola alam menjadi wisata pantai, pegunungan, air terjun, edukasi pertanian sesuai dengan keinginan dan kemampuan masyarakat. Model lainnya dengan memberikan pelatihan keterampilan pengolahan sampah, batik, dan hidroponik. Dan terakhirnya, model pemberdayaan dengan memberikan bantuan hukum, misalnya dengan mendapatkan jaminan kesehatan dan ekonomi, perlindungan dari kekerasan.

Pemberdayaan menjadi salah satu upaya mengentaskan permasalahan kemiskinan dengan cara mendorong dan membangkitkan kesadaran, agar menyadari bahwa masyarakat memiliki potensi yang dapat dioptimalkan. Potensi tersebut harus dikelola untuk kegiatan yang nyata, sehingga hasilnya pun nyata. ${ }^{7}$ Pemberdayaan sebagai upaya pemecahan masalah masyarakat, dengan melakukan pembangunan pada masyarakat yang bertumpu pada masyarakat itu sendiri. 8 Menurut

\footnotetext{
${ }^{6}$ Mahmuda, "Dakwah Dan Pemberdayaan."

${ }^{7}$ Zubaedi, Pengembangan Masyarakat: Wacana Dan Praktik (Jakarta: Kencana Pranada Media Grup, 2013), 24.

8 Rahman Mulyawan, Masyarakat, Wilayah, Dan Pembangunan, Bandung: UNPAD [Universitas Padjadjaran] Press. Tersedia Secara Online Juga Di: Http://Pustaka. Unpad. Ac. Id/WpContent/Uploads/2016/10/04-Buku-OK_opt. Pdf [Diakses Di Lembang, Jawa Barat, Indonesia: 9 Oktober 2018] (Bandung: UNPAD press, 2016), 60-66.

9. Ibid., 67-68.
}

Kartasasmita dan Mulyawan, pemberdayaan dapat dilakukan dengan berprinsip pada hal berikut: ${ }^{9}$ (1) menciptakan suasana yang dapat meyakinkan masyarakat bahwa dirinya memiliki potensi yang dapat dikembangkan. Masyarakat perlu diberikan penjelasan peluang apa saja yang dimiliki dan dimanfaatkan; (2) masyarakat perlu diajak mengimplementasikan potensi diri dengan terus menguatkan dengan pelatihan; (3) melindungi dari dinamika yang akan dihadapi, sehingga masyarakat bisa melalui hambatan yang ada.

Potensi yang dimiliki masyarakat yang dapat dijadikan sebagai alat untuk membuat masyarakat menjadi berdaya disebut aset komunitas masyarakat atau modal. ${ }^{10}$ Robert Putnam menjelaskan bahwa, modal sosial dapat membangun kekuatan lokal untuk kemudian bersama-sama melakukan pembangunan masyarakat dengan hasil peningkatan ekonomi masyarakat. ${ }^{11}$ Modal sosial sebagai salah satu aset masyarakat ketika dapat dikelola dengan baik, akan membantu mensukseskan kegiatan pemberdayaan masyarakat. Masyarakat perlu disadarkan bahwa kemiskinan itu bisa diselesaikan jika komunitas masyarakat mau bersama-sama melakukan perubahan dengan mengoptimalkan aset yang dimiliki. ${ }^{12}$

\footnotetext{
10. Abdillah Ubaidi Djawahir, "Asset Based Community Development Di Pesantren Wisata: Implementasi Strategis Di PP. An-Nur 2 Al Murtadlo Malang," AtTamkin: Jurnal Pengabdian Kepada Masyarakat 1, no. 1 (2018): 23-34, doi: https://doi.org/10.33379/attamkin.v1i1.95

11. Dereau Christoper, "Pembaru Dan Kekuatan Lokal Untuk Pembangunan," TT: Australian Community Development and Civil Society Strengthening Scheme (ACCESS), 2013, 45.

12. Syaiful IImi, "Konsep Pengentasan Kemiskinan Perspektif Islam," Jurnal Al-Mas/ahah 13, no. 1 (2017): 67-84, doi: doi.org/10.24260/almaslahah.v13i1.918
} 
Di sisi lain, kondisi global telah memasuki era kemajuan teknologi informasi, oleh karenanya masyarakat perlu memikirkan bagaimana kemajuan teknologi yang ada dapat dimanfaatkan untuk memecahkan masalah kemiskinan yang dihadapinya. Sehingga, masyarakat dapat menggunakan peluang teknologi yang ada dalam kegiatan pemberdayaan.

Prinsip pemberdayaan di atas, dapat ditemui pada organisasi Kampung Marketer atau disingkat KM yang melakukan pemecahan masalah kemiskinan dengan memanfaatkan peluang perkembangan teknologi dan memerankan aset yang ada di desa. Sebagaimana yang dijelaskan dalam penelitian Mahmud, Wijaya, dan Kartono, bahwa modal sosial yang dimiliki Kampung Marketer yakni ikatan pemuda desanya mampu membuat KM sukses menjalankan kegiatannya. Kedekatan pemuda ini membuat para pemuda bisa bekerja sama dengan baik dalam membentuk komunitas dan melakukan kegiatan pelatihan digital marketing. ${ }^{13}$ Kesuksesan KM tidak lepas dari aset komunitas di desa ini, selain aset sosial di atas, ada aset lain yang diperankan oleh KM, misalkan aset fisik berupa rumah-rumah di desa. Maka, perlu untuk mendalami bagaimana peranan aset komunitas desa dalam kegiatan pemberdayaan KM.

Kampung Marketer dirintis Nofi Bayu Darmawan pada tahun 2017. Nofi adalah pemuda desa yang memiliki keahlian dalam

\footnotetext{
13 Imam Mahmud, Mahendra Wijaya, and Drajat Tri Kartono, "Bonding, Bridging, And Linking Social Capital In Empowering Youth In Kampung Marketer, Indonesia," International Journal of Education and Social Science Research 3, no. 05 (2020): 99-108, doi.org/10.37500/IJESSR.2020.3508.

${ }^{14}$ Arbi Anugrah, "Mengintip Kampung Bisnis Online DI Purbalingga," Detikinet, March 13, 2018,
}

bidang digital marketing. Kampung Marketer didirikan karena Nofi melihat para pemuda desa banyak yang kesulitan mencari pekerjaan karena wilayahnya adalah pedesaan, yang kedua karena melihat banyak para pemuda desa melakukan urbanisasi ke kota karena mencari pekerjaan di kota, akhirnya ada kesenjangan di desa karena kehilangan pemuda. ${ }^{14}$

Setelah lima bulan berjalan, jumlah pemuda mau bergabung menjadi anggota pelatihan dan SDM yang bekerja dengan mitra bisnis 200 pemuda. Partner yang bekerja sama dengan Kampung Marketer sebanyak 62 partner bisnis mulai dari pemilik brand, reseller hingga dropshipper, Nofi menargetkan Kampung Marketer bisa memberdayakan masyarakat desa sekitar 1.000 orang pada tahun ke- $4 .{ }^{15}$ Pada tahun 2020, jumlah mitra pengusaha yang bekerja sama dengan KM adalah 218. Pemuda yang mau bergabung 748 orang. Perputaran uang untuk gaji sejumlah 1,4 miliar sebulan, serta memiliki 26 rumah warga yang disewa untuk pusat pemberdayaan. ${ }^{16}$

Penghargaan yang didapatkan oleh KM ini dari berbagai pihak yakni Penggerak Wirausaha Muda Berprestasi Kemenpora RI, Liputan 6 Awards SCTV 2018, NET, INews, Antara TV, Kompas, Detik.com, Wirausaha Muda Mandiri 2019, SDG PIPE 2019, Pemuda Pelopor Pembangunan 2018, TechTo Impact, Young Changemakers Social Enterprise Academy 2.0, Hyundai Start Up. ${ }^{17}$

https://inet.detik.com/cyberlife/d-

3906135/mengintip-kampung-bisnis-online-dipurbalingga.

$15 \mathrm{lbid}$.

${ }^{16}$ Kampung Marketer, "Kolaborasi Yang Berdampak," Kampung Marketer, March 27, 2021 https://kampungmarketer.com/.

17. Ibid. 
Kegiatan pemberdayaan KM ini dibarengi juga dengan upaya peningkatan keimanan anggota yang bergabung. Anggota yang tergabung menjadi lebih religious, misalkan saja dari aspek kebiasaan mereka mulai menerapkan salat tepat waktu, dan pakaiannya lebih Islami. Semua capaian itu karena ada beberapa program yang dijalankan, antara lain; (1) Salat berjamaah setiap hari ketika jam kerja khususnya Salat Dzuhur. Kegiatan ini dilakukan di musala atau masjid sekitar kantor; (2) Program Pengajian dengan mendatangkan penceramah untuk meningkatkan keimanan SDM; (3) Program membaca Al-Qur'an terutama saat bulan ramadan diadakan pesantren kilat; (4) Program motivasi keagamaan dari Kementerian Agama untuk memberikan pengetahuan tentang agama; (5) Program berpakaian tertutup sesuai syariat Islam, khususnya wanita harus berjilbab, bahkan pada hari jum'at harus menggunakan gamis. ${ }^{18}$ Kampung Marketer memiliki semangat pemberdayaan yang bernilai kesejahteraan dunia dan akhirat sebagaimana prinsip dakwah bil hal.

18 Riris Wahidatul Munawaroh, "Implementasi Pendidikan Karakter DIsiplin Beribadah Dalam Komunitas Bisnis Online Kampung Marketer Tanjungmuli Karangmoncol Purbalingga" (Institut Agama Islam Negeri Purwokerto, 2020), 91-96, http://repository.iainpurwokerto.ac.id/id/eprint/7312

19 Muhammad Fedryansyah and Risna Resnawaty, "Penganggulangan Kemiskinan Melalui Pengembangan Aset Komunitas," Share: Social Work Journal 7, no. 1 (2017): 124-29, doi.org/10.24198/share.v7i1.13828.

${ }^{20}$ Wahanani Mawasti and Fasha Umh Rizky, "Peranan Aset Komunitas Dalam Pengembangan Masyarakat Islam Pada Bank Sampah Songolikoer," INTELEKSIAJurnal Pengembangan Ilmu Dakwah 2, no. 01 (2020): 27-54,

http://inteleksia.stidalhadid.ac.id/index.php/inteleksi a/article/view/83.

${ }^{21}$ Imam Mahmud, Mahendra Wijaya, and Drajat Tri Kartono Kartono, "Kampung Marketer Sebagai
Studi terdahulu tentang peranan aset komunitas dalam pemberdayaan, pertama studi Muhammad Fedryansyah dan Risna Resnawaty. ${ }^{19}$ Studi ini menjelaskan aset yang dimiliki masyarakat yang dapat digunakan memecahkan masalah kemiskinan. Studi ini tidak menjelaskan peranan aset. Kedua, Studi Wahanani Mawasti dan Fasha Umh Rizky. ${ }^{20}$ Studi ini menjelaskan peranan aset dalam pemberdayaan masyarakat melalui Bank sampah Songolikoer, studi ini menjelaskan aset komunitas diperankan untuk membuat masyarakat berdaya, namun kegiatan pemberdayaannya pada bank sampah, sehingga ada perbedaan objek kajian. Ketiga, Studi Mahmud, Wijaya, dan Kartono. ${ }^{21}$ Studi ini menjelaskan langkah yang dilakukan Kampung Marketer dalam melakukan kegiatan pemberdayaan. Penelitian ini tidak mengulas terkait aset sosial, hanya menjelaskan model kegiatan pemberdayaan oleh Kampung Marketer, proses pemberdayaan secara umum. Keempat, Studi Nur Chasanah. ${ }^{22}$ Studi ini, menjelaskan bagaimana alur manajemen pengetahuan Kampung Marketer, bagaimana proses pemberian materi digital

Pemberdayaan Masyarakat Melalui Pendidikan Online Marketing Di Era Revolusi Industri 4.0 (Studi Kasus Desa Tamansari, Karangmoncol, Purbalingga)," in Prosiding Seminar Nasional IImu Sosial Dan Politik: Media Baru Dan Wajah Masyarakat Pasca Revolusi Industri 4.0, Universitas Sebelas Maret (UNS (Sebelas Maret University), 2019), 22-28, https://digilib.uns.ac.id/dokumen/detail/66891/Kamp ung-Marketer-sebagai-Pemberdayaan-Masyarakatmelalui-Pendidikan-Online-Marketing-di-Era-RevolusiIndustri-40-Studi-Kasus-Desa-TamansariKarangmoncol-Purbalingga.

22 Nur Chasanah, "Implementasi Knowledge Management Dengan Pendekatan Soft System Methodology (Studi Kasus: Kampung Marketer, Purbalingga)," in Prosiding Nasional Rekayasa Teknologi Industri Dan Informasi XIII, 2018, 142-48, https://journal.itny.ac.id/index.php/ReTII/article/view /1089. 
marketing, subjek yang dilibatkan, infrastrukturnya. Kajiannya hanya pada proses pemberian pelatihan saja. Kelima, studi Mahmud, Wijaya, dan Kartono. ${ }^{23}$ Studi ini, menjelaskan bagaimana peranan modal sosial dalam kegiatan pemberdayaan Kampung Markter kepada pemuda desa, mulai dari hubungan antara subjek dan objek pemberdayaan, serta mitra usaha. Studi ini, hanya pada peranan modal sosialnya saja.

Dari studi, terdahulu yang sudah ada, studi peranan aset dalam pemberdayaan masyarakat belum banyak dikaji. Studi terhadap Kampung Marketer masih seputar proses kegiatan pemberdayaannya saja, tidak menjelaskan peranan aset dalam proses input dan outputnya, ada juga yang meneliti peranan modal sosial saja, padahal untuk bisa memberdayakan masyarakat tak cukup hanya dengan modal sosial, sehingga perlu diperdalam kajian terhadap aset-aset lainnya.

Oleh karenanya, studi peranan aset komunitas oleh KM perlu dilakukan untuk mendalami peranan aset komunitas yang dilakukan KM dalam kegiatan pemberdayaan, baik aset manusia, fisik, finansial, sosial sehingga masyarakat dapat keluar dari masalah kemiskinan, dan menjadi mandiri dengan memanfaatkan aset yang ada dari internal komunitas mereka. Studi ini, diharapkan bermanfaat untuk referensi bagi subjek pemberdayaan yang juga ingin mengoptimalkan aset-aset masyarakat karena sesungguhnya mereka memiliki banyak potensi, namun potensi tersebut tidak dijadikan aset yang sangat bermanfaat untuk pemberdayaan. Studi ini, juga dapat

\footnotetext{
${ }^{23}$ Mahmud, Wijaya, and Kartono, "Bonding, Bridging, And Linking Social Capital In Empowering Youth In Kampung Marketer, Indonesia," 99-108.
}

menjadi referensi bagaimana melakukan pengembangan masyarakat Islam melalui dakwah bil hal, dengan melakukan pemberdayaan ekonomi masyarakat yang didalamnya juga terdapat pengenalan nilai Islam.

Studi ini merupakan studi kualitatif. Sehingga, studi ini nantinya akan menggambarkan pemeranan aset yang dilakukan oleh KM dalam melakukan pemberdayaan pemuda desa di Purbalingga dengan memberikan skill yang berkaitan dengan digital marketing. Studi ini, menggunakan teknik penggalian data wawancara pengurus dan menggali dari data pustaka yakni bahan koleksi perpustakaan dan internet. ${ }^{24}$ Narasumber adalah SDM Bidang Pemberdayaan Masyarakat Kampung Marketer, Hendrik. Narasumber dipilih karena memahami bagaimana proses pemeranan aset-aset komunitas yang digunakan dalam pemberdayaan. Wawancara dilakukan secara virtual karena pandemi. Sumber pustaka meliputi video YouTube liputan wawancara kepada pendiri Kampung Marketer yakni saudara Nofi Bayu Darmawan, dan website resmi Kampung Marketer.

\section{Aset Komunitas dalam Pemberdayaan}

Aset komunitas dalam pemberdayaan adalah sumber daya yang dimiliki dan digunakan dalam kegiatan pemberdayaan masyarakat. Menurut Siregar, aset adalah barang atau sesuatu yang memiliki nilai ekonomis, nilai komersial atau nilai tukar

\footnotetext{
24 Khatibah, "Penelitian Kepustakaan," Iqra': Jurnal Perpustakaan Dan Informasi 5, no. 01 (2011): 36-39, http://repository.uinsu.ac.id/id/eprint/640.
} 
yang dimiliki individu ataupun instansi tertentu. ${ }^{25}$ Aset adalah sumber daya yang dapat mendukung atau bermanfaat untuk pencapaian tujuan kehidupan masyarakat, salah satunya adalah mengentaskan masalah kemiskinan. Setiap aset memiliki kedudukan dan daya dukung atau peranan yang berbeda bagi kehidupan masyarakat. ${ }^{26}$ John L. McKnight \& Cormac Russel menjelaskan aset lokal yaitu sumber daya yang dimiliki dan digunakan oleh masyarakat untuk meningkatkan kesejahteraan masyarakat. Setiap masyarakat pasti memiliki aset lokal. ${ }^{27}$ Aset lokal atau dalam istilah lainnya disebut sebagai aset komunitas. ${ }^{28}$ Menurut Sunyoto Usman dalam kegiatan yang berorientasi ekonomi maupun manfaat sosial dapat menggunakan sumber daya untuk mencapai tujuannya. Suatu komunitas dapat mengadakan dan mengembangkan sumber daya yang ada. Sumber daya tersebut atau disebut dengan modal terdiri atas: modal finansial, modal fisik, modal manusia, dan modal sosial. Pada konteks pemberdayaan, maka maksud dari modal ini adalah diperuntukkan untuk memperoleh manfaat sosial. ${ }^{29}$ Modal yang dimiliki suatu komunitas disebut sebagai modal kolektif. ${ }^{30}$ Modal ini disebut sebagai aset karena modal tersebut digunakan, dikelola, dan dikembangkan dalam kegiataan produktif.

25 Aras Aira, "Peran Manajemen Aset Dalam Pembangunan Daerah," Kutubkhanah 17, no. 1 (2015): 21-39, http://ejournal.uinsuska.ac.id/index.php/Kutubkhanah/article/download /807/767.

${ }^{26}$ Adhiana, "Analisis Identifikasi Pemilikan Aset Petani Pasca Tsunami Di Aceh," Agrifo: Jurnal Agribisnis Universitas Malikussaleh 2, no. 2 (2017): 34-49, doi.org/10.29103/ag.v2i2.367.

27 John L McKnight and Cormac Russell, "The Four Essential Elements of an Asset-Based Community
Kesimpulan dari penjelasan di atas, aset komunitas adalah modal yang dimiliki komunitas pemberdayaan, modal tersebut dimiliki atau bisa diakses komunitas, kemudian digunakan untuk kegiatan pemberdayaan yang bertujuan untuk memperoleh manfaat sosial yakni kesejahteraan. Aset dapat diperankan dalam kegiatan pemberdayaan.

Jenis aset komunitas yang dapat diperankan dalam suatu kegiatan produktif pemberdayaan untuk mendapatkan manfaat sosial antara lain: ${ }^{31}$ (1) Aset finansial adalah dana yang dimiliki oleh perorangan, organisasi, ataupun komunitas untuk digunakan dalam kegiatan produktif. Kegiatan tersebut mengupayakan dana yang ada dikelola, ditingkatkan, dialokasikan, dan digunakan. Dana ini tidak hanya disimpan saja sebagai tabungan; (2) Aset fisik adalah infrastruktur utama yang digunakan dalam kegiatan produktif. Infrastruktur tersebut bisa berupa gedung, mesin, komputer, dan peralatan lainnya yang dijadikan bahan utama dalam kegiatan produktif; (3) Aset manusia adalah manusia dengan segala aspek pengetahuan, keterampilan, kepandaian, pengalamannya, yang diposisikan sebagai sumber daya yang bergerak dengan melakukan suatu kegiatan produktif untuk memperoleh manfaat sosial; (4) Aset sosial adalah aset berupa relasirelasi sosial, nilai-nilai sosial, norma-norma

Development Process," What Is Distinctive about Asset-Based Community Process 15 (2018): 3.

${ }^{28}$ Djawahir, "Asset Based Community Development Di Pesantren Wisata: Implementasi Strategis Di PP. AnNur 2 Al Murtadlo Malang," 24.

${ }^{29}$ Sunyoto Usman, Modal Sosial (Yogyakarta: Pustaka Pelajar, 2018), 1.

30 Ibid., 7.

31 Ibid., 2-4. 
sosial yang digunakan untuk melakukan kegiatan produktif.

\section{Peranan Aset Komunitas dalam Pemberdayaan}

Peranan aset komunitas dalam pemberdayaan adalah tentang modal yang dimiliki komunitas tidak hanya didiamkan saja sebagai sesuatu yang potensial, namun dikelola dengan digunakan hingga dikembangkan untuk mendukung upaya kinerja mencapai tujuan manfaat sosial, berupa kegiatan produktif yaitu kegiatan pemberdayaan. ${ }^{32}$

Pemberdayaan keluarga miskin dapat memerankan aset komunitas yang dimiliki. Misalnya, set fisik dapat diperankan sebagai wadah/tempat kegiatan pemberdayaan, aset finansial dapat diperankan sebagai sumber dana operasional termasuk dana modal usaha atau pinjaman usaha keluarga miskin, aset manusia dapat diperankan sebagai subjek yang melakukan kegiatan pemberdayaan, aset sosial diperankan dalam membangun ikatan untuk saling membantu antara subjek dan objek pemberdayaan, serta aset spiritual dapat diperankan sebagai nilai yang membuat subjek agar senantiasa semangat melakukan kegiatan pemberdayaan. ${ }^{33}$

Sebagaimana yang dicontohkan oleh Bank sampah Songolikoer, aset berupa sampah yang dulunya dianggap menganggu, diperankan sebagai produk yang dapat

32 Ibid., 1-2.

33 Ida Purwastuty, "Pemberdayaan Keluarga Miskin Melalui Aset Komunitas," Jurnal Mimbar Kesejahteraan Sosial 1, no. 1 (2018): 1-14, http://journal.uin-

alauddin.ac.id/index.php/jmks/article/download/700 9/5788. dijual, dan memberikan masukan dana. Aset manusia ibu-ibu rumah tangga yang sebelumnya hanya berdiam diri dan tidak memahami potensi sampah, diperankan sebagai subjek aktif, mereka menjadi memiliki pengetahuan tentang pengelolaan sampah dan memiliki aktivitas mengolah sampah hingga mendapatkan pemasukan membantu ekonomi keluarganya. Aset spiritual berperan sebagai nilai yang membuat masyarakat semangat meski tidak banyak keuntungan material dalam kegiatan pemberdayaan bank sampah. Aset sosial juga diperankan sebagai media koordinasi masyarakat. $^{34}$

Peranan aset juga bisa berupa memerankan aset lingkungan, misalnya aset pegunungan, pantai, perbukitan, bendungan, taman bunga, dan bahkan makam, yang memiliki keindahan, dapat dijadikan sebagai atraksi produk yang dapat mengundang wisatawan. Pengelolaan itu tentunya melibatkan aset manusia yakni warga desa. Warga terlibat mulai dari menganalisa potensi alam, desain pengembangan wisata, dan pengelola wisata. Aset finansial, setiap masyarakat desa pasti memiliki dana desa, dana tersebut dapat dijadikan modal untuk membiayai semua kegiatan pemberdayaan sampai akhirnya kegiatan tersebut dapat membiayai secara mandiri. ${ }^{35}$

Aset manusia berupa kelompok sosial budidaya ikan koi di desa Banyuglugur, diperankan sebagai subjek aktif, mereka diberikan pengetahuan tentang budidaya

\footnotetext{
${ }^{34}$ Mawasti and Rizky, "Peranan Aset Komunitas Dalam Pengembangan Masyarakat Islam Pada Bank Sampah Songolikoer," 27-54.

35 Noor Rochman, "Model Pengembangan Desa Wisata Berbasis Pemberdayaan Masyarakat," Jurnal Equilibria Pendidikan 1, no. 1 (2016): 59-69, doi.org/10.26877/ep.v1i1.1831.
} 
ikan, dan memasarkan ikan, hasilnya budidaya ikan koi dapat menjadi pemasukan ekonomi mereka. ${ }^{36}$

Aset lingkungan berupa eceng gondok yang tumbuh subur di sungai, diperankan menjadi produk olahan makanan yang bernilai jual tinggi sehingga menjadi pemasukan ekonomi. Studi ini, juga menjelaskan cara mengelola aset manusia yakni masyarakat desa dengan memberikan pelatihan membuat olahan makanan serta memasarkan produk olahan makanan. Serta aset finansial berupa Kube beserta variable kelembagaannya sebagai koperasi yang membantu dalam hal dana kegiatan pemberdayaanya. ${ }^{37}$

Studi peranan aset komunitas diatas memberikan contoh tentang aset-aset yang dimiliki masyarakat dapat diperankan dalam kegiatan pemberdayaan. Aset manusia dapat diperankan sebagai objek dan subjek aktif kegiatan pemberdayaan, aset lingkungan dapat dijadikan produk pemberdayaan yang bernilai jual tinggi, aset finansial dapat membiayai seluruh proses kegiatan pemberdayaan, aset fisik dapat dijadikan sebagai pusat koordinasi dan kegiatan pemberdayaan, aset spiritual untuk membangun semangat masyarakat agar mereka konsisten menjalankan kegiatan pemberdayaan, aset sosial berperan sebagai media koordinasi masyarakat.

\section{Kampung Marketer}

Kampung Marketer adalah organisasi yang melakukan pemberdayaan ke masyarakat dengan memberikan pelatihan dan pendidikan terkait teknologi spesifiknya digital marketing atau pemasaran online. Penjualan online di lapak seperti Tokopedia, Shopee, Lazada, Blibli, menuntut para pembeli dan penjual cukup berkomunikasi di akun online mereka. Para penjual itu harus melakukan update barang yang dijual semenarik mungkin di lapak, melayani pertanyaan pembeli terkait produk, memecahkan masalah komplain setelah pembelian.

KM menyediakan SDM ahli dibidang tersebut. KM memberikan pelatihan untuk pemuda desa terkait skill digital marketing, lalu bekerjasama dengan mitra bisnis berupa UMKM yang berjualan online. Sehingga, setelah anggota KM menyelesaikan pelatihan, mereka dapat bergabung menjadi SDM yang akan bekerja dengan mitra bisnis KM. ${ }^{38}$ Subjek yang menjadi sasaran adalah pemuda desa Tamansari, Kecamatan Karangmoncol, Purbalingga. ${ }^{39}$

alauddin.ac.id/index.php/jmks/article/view/10981/72 10.

38 Nofi Bayu Darmawan, "MPLS - Pemanfaatan Teknologi dalam Dunia Digital Marketing Bersama Kampung Marketer," interview by Aries Cahya R, Youtube, 22:06, SMK Negeri 4 Pekalongan, march 26, 2021.

https://www.youtube.com/watch?v=chx4PsZi6bk.

39 Fianingsih, "Pemberdayaan Masyarakat Melalui Kampung Marketer - Studi Kasus Desa Tamansari Kecamatan Karangmoncol Kabupaten Purbalingga" (Institut Agama Islam Negeri Purwokerto, 2020), 8. 
Bentuk organisasi ini adalah social enterprise. Didirikan secara swadaya oleh Nofi Bayu D. Kemudian berkembang menjadi perusahaan besar yang bertujuan memberdayakan masyarakat. ${ }^{40}$ Saat ini, Kampung Marketer menjadi organisasi $e$ Commerce atau start up namun berorientasi pemberdayaan sosial, sehingga tidak seperti organisasi bisnis pada umumnya yang hanya melatih SDM untuk tujuan keuntungan semata, tetapi Kampung Marketer memberikan pelatihan secara gratis untuk memberi daya pada pemuda desa, kemudian mereka bisa bekerja untuk menjadi SDM marketer secara profesional ataupun mendirikan usaha sendiri dengan memanfaatkan skill yang sudah didapat. ${ }^{41}$

Kampung Marketer berdiri pada 27 Agustus 2017. Pada 1 Januari 2021, KM berubah nama menjadi Komerce. Informasi terkait Komerce dapat dicari di Komerce.id. Pusat kegiatan Kampung Marketer terletak di Desa Tamansari, Kecamatan Karangmoncol, Kabupaten Purbalingga. ${ }^{42}$ Visi Kampung Marketer yaitu: “Mengurangi pengangguran untuk skala muda melalui teknologi, mengurangi urbanisasi dari desa ke kota, menciptakan technopreneur yang terlahir dari desa." ${ }^{43}$ Misi KM yaitu: (1) menyusun kurikulum dan metodologi Pendidikan di bidang IT berbasis marketing online bagi masyarakat Karangmoncol; melaksanakan pendidikan dan pelatihan melek IT untuk membentuk masyarakat

\footnotetext{
40 Nofi Bayu Darmawan, "Leader Talk Nofi Bayu (Founder Kampung Marketer)," interview by lim Rusyamsi, Youtube, 45:18, Okoce.Indonesia, March 26, 2021. https://www.youtube.com/watch?v=figeMj59RI.

$\overline{41}$ Hendrik (Pengurus Departemen Pemberdayaan). Wawancara dengan Suciati, Kampung Marketer Surabaya, 6 Maret, 2021.

42 Fianingsih, "Pemberdayaan Masyarakat Melalui Kampung Marketer - Studi Kasus Desa Tamansari
}

Karangmoncol yang terampil di bidang IT yang berbasis marketing online; (3) memberdayakan masyarakat Karangmoncol yang sudah melek IT berbasis marketing online untuk dapat berjejaring dengan mitra sebagai bentuk keberlanjutan untuk meningkatkan pendapatan. ${ }^{44}$

Kepengurusan KM diambil dari pemuda yang sudah bergabung, dari internal desa. Struktur KM ada pimpinan: Novi Bayu Darmawan selaku founder Kampung Marketer. Kepala bidang tata usaha yang meliputi sarana prasarana usaha, keuangan, IT support, dan kepegawaian. Kepala bidang pemberdayaan yang meliputi supervisor leader dan di bawahnya ada Leader SDM. Kepala bidang pendidikan yang meliputi pengajar digital marketing, pengajar CS (custome rservice), dan program kurikulum \& on boarding. Kepala bidang pertumbuhan yang meliputi web development, growth staff, kominfo, dan public relation. ${ }^{45}$

Awalnya KM ini diinisiasi oleh Nofi Bayu. Beliau sebagai subjek yang menggagas Kampung Marketer. Dulunya seorang mahasiswa di sekolah tinggi akuntansi negara, sekaligus pekerja pemasaran online untuk produk seprai. Bekerja di kementerian keuangan, lalu keluar dan mengelola toko daringnya pada produk mainan anak dan produk perawatan kulit. Lalu menginisiasi Kampung Marketer. ${ }^{46}$ Kemudian Nofi, bersama Pemuda yang sudah merasakan

\footnotetext{
Kecamatan Karangmoncol Kabupaten Purbalingga," 40.

${ }^{43}$ Darmawan, "Leader Talk".

44 Fianingsih, "Pemberdayaan Masyarakat Melalui Kampung Marketer - Studi Kasus Desa Tamansari Kecamatan Karangmoncol Kabupaten Purbalingga," 42.

45 Ibid., 43.

46 Megandika Wicaksono, "Nofi Bayu Darmawan, Mendorong Anak Muda Melek Teknologi," March 26,
} 
manfaat skill digital marketing berinisiatif bergabung dan membentuk organisasi. Pengurus KM ini yang banyak memberikan gagasan tentang konsep pemberdayaan KM.

\section{Tahapan Pemberdayaan Pemuda Kampung Marketer}

Pemeranan aset menyesuaikan dengan tahapan pemberdayaan yang dilakukan subjek pemberdayaan. Tahapan-tahapan pemberdayaan meliputi; (1) Tahap penyadaran, yakni tahapan membentuk perilaku sadar masyarakat bahwa mereka harus berubah dan mengikuti kegiatan pemberdayaan; (2) Tahap pengkapasitasan, yakni tahap pelatihan kepada masyarakat agar memiliki kemampuan yang dibutuhkan agar ke depan masyarakat dapat mandiri; (3) Tahap peningkatan kemampuan intelektual, masyarakat dapat secara mandiri melakukan pembangunan, masyarakat dapat menjadi subjek pembangunan, sehingga mereka mulai mengimplementasikan kegiatan pemberdayaan dengan hasil peningkatan kesejahteraan. ${ }^{47}$

Tahap pemberdayaan KM dimulai dari tahap penyadaran dengan memberikan informasi, kesadaran, dan motivasi pada masyarakat khususnya pemuda desa di Purbalingga untuk ikut bergabung dengan kegiatan pemberdayaan KM ini. Tahap awal Nofi Bayu menyebarkan edaran di blog berupa lowongan kerja menjadi pemasar online. Hasil dari proses tersebut tidak ada satu pun

2021,

https://www.kompas.id/baca/sosok/2018/03/23/nofi -bayu-darmawan-mendorong-anak-muda-melekteknologi.

47 Erna Dede Fujiani, Yus Darusman, and Lesi Oktiwanti, "Pemberdayaan Perempuan Kepala Keluarga (PEKKA) Melalui Pelatihan Berwirausaha," Indonesian Journal of Adult and Community Education pemuda yang mendaftar. Hal ini, dimungkinkan karena pada pemuda di Purbalingga ini tidak memiliki skill yang berkaitan dengan teknologi, maka otomatis mereka tidak akan mendaftar menjadi SDM dari KM. Kegagalan tersebut membuat Nofi Bayu mengubah strateginya menjadi sistem door to door mendatangi pemuda desa, diajak untuk bergabung dalam kegiatan pelatihan digital marketing, jika sudah memiliki kemampuan kemudian dapat menjadikan skillnya tersebut sebagai SDM pemasaran online. ${ }^{48}$ Dalam tahap ini, Nofi Bayu memberi tawaran hanya kepada orang terdekat, dimulai dari keluarga. ${ }^{49}$ Awal Nofi mendapatkan dua orang pemuda yang dipandang benar-benar memiliki minat dengan pelatihan digital marketing. Dua pemuda itu pun sukses. ${ }^{50}$

Kemudian, Bayu menawari beberapa pemuda, karena sudah ada contoh dua orang pemuda yang mampu menguasai skill pelatihan digital marketing dan memiliki pekerjaan menjadi SDM pemasaran online dengan gaji yang tinggi. ${ }^{51}$ Sistem perekrutan ini melalui seminar informal di balai desa, jadi Nofi bayu menceritakan terkait digital marketing dan prospeknya di Balai desa. Hasilnya, banyak pemuda yang memutuskan bergabung. Meski masih ada juga pemuda yang tidak memahami maksud digital marketing lalu tidak ikut, dan meragukan pelatihan ini sebagai sistem multi level marketing yang menipu. Setelah terkumpul beberapa orang, beberapa tahap

1, no. 1 (2019): 20-25, https://ejournal.upi.edu/index.php/IJACE/article/vie w/20002.

48 Darmawan, "Leader Talk."

${ }^{49}$ Hendrik, interview.

50 Darmawan, "MPLS."

51 Darmawan, "Leader Talk." 
penyadaran di balai desa, kemudian membentuk komunitas. Komunitas ini kemudian sukses. Akhirnya semakin tersebar kesuksesan KM ini. ${ }^{52}$

Informasi KM kini dapat diketahui melalui spanduk yang disebar di kantor KM yang berisi ajakan gabung Kampung Marketer dengan berbagai infomasi prospektus dan ketentuannya, lalu pemuda yang minat bisa mendaftar dan membawa surat lamaran kerja. KM membuka kesempatan pemuda yang membutuhkan suatu pekerjaan. ${ }^{53}$ Pemuda yang bergabung pun semakin banyak, lalu diberikan pelatihan dan pekerjaan. ${ }^{54}$

Penyadaran terus dilakukan kepada banyak pemuda lainnya melalui memasang informasi di beberapa area kantor KM. Cara tersebut kini menjadi efektif karena masyarakat sudah merasakan powerfull impact. Misalnya, dengan tersebarnya informasi pemuda desa yang berhasil berlatih dan mendapatkan pekerjaan dengan gaji tinggi. Jika pada tahap awal penyadaran banyak yang tidak mau ikut karena mereka tidak memahami pentingnya teknologi, tidak yakin jika mereka akan mampu memiliki kemampuan teknologi, dan tidak yakin akan prospektus pekerjaan yang ada. Dengan adanya impact yang nyata dan tersebar di desa, melalui mulut ke mulut saat masyarakat berinteraksi dengan saudara atau tetangga, kemudian pemuda mulai banyak yang minat dengan Kampung Marketer. Kesadaran itu muncul karena adanya bukti riel. ${ }^{55}$

\footnotetext{
52 lbid.

53 Fianingsih, "Pemberdayaan Masyarakat Melalui Kampung Marketer - Studi Kasus Desa Tamansari Kecamatan Karangmoncol Kabupaten Purbalingga," 45-46.

${ }^{54}$ Darmawan, "MPLS".
}

Tahap kedua yang dilakukan oleh KM adalah memberikan pelatihan untuk pemuda yang mau bergabung dengan KM agar terjadi penguatan daya atau pengetahuan dan skill dalam digital marketing. Kurikulum yang diberikan dimulai dari digital marketing, customer service, manajemen sosmed. ${ }^{56}$ Keterampilan yang diajarkan dalam bidang IT di antaranya; ${ }^{57}$ (1) customer Service, keterampilan mengelola calon pembeli melalui aplikasi chating. Biasanya aplikasi yang digunakan adalah Whatsapp dan facebook. Keterampilan ini diajarkan supaya anggota bisa melayani hal-hal berkaitan dengan pembelian dengan fitur-fitur komunikasi yang ada; (2) advertiser, yaitu kemampuan membuat iklan untuk menawarkan produk tertentu kepada calon pembeli. Anggota diajarkan cara membuat iklan tertentu untuk sebuah brand. Strategi iklan ini asumsinya berupa digital, karena kemampuan utama yang diajarkan pemasaran online, yaitu; (3) social Media Admin, keterampilan menjaga interaksi, mengelola calon pembeli maupun pelanggan di channel social media sebuah brand, yaitu; (4) content Writer, keterampilan memproduksi sebuah konten yang menarik untuk sebuah brand di media online. Adapun cara memproduksi sebuah konten artikel/ penawaran produk biasanya pada blog maupun sales page.

Tahapan pelatihan tidak hanya untuk memberikan wawasan dan skill terkait digital marketing, tetapi juga memberikan pendidikan karakter disiplin beribadah dan

\footnotetext{
55 Ibid.

56 Darmawan, "MPLS."

57 Fianingsih, "Pemberdayaan Masyarakat Melalui Kampung Marketer - Studi Kasus Desa Tamansari Kecamatan Karangmoncol Kabupaten Purbalingga," 46-47.
} 
bekerja. Founder dan anggota memasukkan nilai agama itu dalam program pemberdayaan mereka. Dimulai ketika program pelatihan saat training menjadi anggota baru. Pada tahap pelatihan upaya peningkatan nilai agama itu diwujudkan dalam program diklat lima hari, program wajib salat Jamaah, peraturan memakai pakaian syar'i, program pengajian rutin untuk semua anggota baru. Upaya ini, dilakukan agar anggota sejak awal bergabung mampu menjadi seorang yang memiliki kerja keras, toleransi, dan amanah. Hal ini, akan memberikan manfaat yang baik dalam kelancaran kegiatan pemberdayaan Kampung Marketer untuk pemuda kedepannya, baik saat masa pelatihan hingga implementasi kegiatan pemberdayaan. ${ }^{58}$

Tahap pelatihan ini, dilakukan di kantor KM. Sistem pelatihan selain diberikan materi, anggota yang bergabung juga langsung melakukan praktik materi yang diajarkan. Oleh karena itu, dalam proses pelatihan ditata ada tempat duduk, meja, laptop dan seluruh perlengkapannya. Para anggota juga dapat menggunakan ponsel yang dimilikinya untuk mengikuti proses pelatihan ini. Para anggota tersebut kemudian, dilatih dengan kurikulum masing-masing, sesuai dengan pilihan bidangnya, selama kurang lebih satu bulan, untuk memberikan pengetahuan dan kecakapan dasar. Setelah, seminggu pengenalan tentang sistem kerja dan kepegawaian. "Jika setelah itu belum mendapatkan pekerjaan, kami akan mengisi

58 Wahidatul Munawaroh, "Implementasi Pendidikan Karakter DIsiplin Beribadah Dalam Komunitas Bisnis Online Kampung Marketer Tanjungmuli Karangmoncol Purbalingga," 77-105.

59 Muhammad Nafi, "Kampung Marketer, Markas Para Pemasar," March 13, 2021, dengan pelatihan tambahan lain," ujar Nofi. ${ }^{59} \mathrm{KM}$ tidak memaksa anggota untuk belajar di bidang tertentu, karena anggota yang bergabung memiliki kebutuhan dan ketertarikan masing-masing, KM kemudian membimbing sesuai kapasitas. ${ }^{60}$ Pada saat pelatihan anggota menyimak pembicara dan langsung praktik.

Pelatihan ini dibuat beberapa tahap, awalnya hanya dua pemuda, kemudian membuka untuk pemuda desa lainnya, jika sudah selesai dilatih dan mendapatkan pekerjaan, maka kemudian dibuka lagi tahap pelatihan untuk pemuda desa lainnya. ${ }^{61}$ Sehingga, pelatihan yang diadakan tidak dalam satu waktu untuk banyak pemuda, namun ada beberapa tahap karena ditentukan juga tenaga pelatih, dana, dan infrastruktur yang ada. KM kini dapat mengajak lebih banyak lagi pemuda desa untuk dilatih skill digital marketing setelah menjadi komunitas. ${ }^{62} \mathrm{KM}$ berdiri sebagai komunitas yang besar, memiliki website sebagai sarana informasi dan penawaran resmi yang menjelaskan tentang program pelatihannya. $^{63}$

Tahap ketiga yang dilakukan KM adalah membantu pemuda desa untuk mendapatkan pekerjaan, pekerjaan sebagai SDM yang bekerja sama dengan mitra bisnis, ataupun pekerjaan berupa menjadi pengusaha sendiri dengan membuka UMKM. Kampung Marketer akan membantu membimbing setiap anggota yang menjadi SDM KM ataupun yang menginisiasi

https://desa.lokadata.id/artikel/kampung-marketermarkas-para-pemasar.

${ }^{60}$ Hendrik, interview.

61 Darmawan, "MPLS."

62 Darmawan, "MPLS."

${ }^{63}$ Anugrah, "Mengintip Kampung Bisnis Online DI Purbalingga." 
pendirian usaha tertentu hingga sukses dan bisa mandiri. ${ }^{64}$ Sehingga, tahap setelah diberikan skill adalah anggota diberdayakan dengan mengoptimalkan skill yang sudah dimiliki, jika anggota telah mampu menyelesaikan pelatihannya, maka sudah memiliki kemampuan digital Marketing, kemudian ditawarkan ke Mitra pengusaha yang membutuhkan SDM untuk pemasaran produknya. ${ }^{65} \mathrm{KM}$ memiliki website sebagai sarana penawaran resmi yang menjelaskan tentang bentuk program pelatihannya dan kerja sama untuk menyalurkan SDM yang sudah selesai dilatih kepada pengusaha yang membutuhkan SDM untuk pemasaran online usaha mereka. ${ }^{66}$

SDM yang bergabung senantiasa didampingi agar mereka bisa bekerja dengan baik, dan apabila ada masalah segera mendapatkan pemecahan. Selain itu, SDM yang bergabung akan terus dibekali dengan pendidikan karakter untuk menjadi seorang muslim yang memiliki keimanan yang senantiasa meningkat, misalkan diberikan peraturan wajib salat berjamaah, berpakaian syar'i, mengaji, mengikuti pengajian. Sehingga, nilai kerja keras, empati, dan amanah akan senantiasa menjadi moral setiap SDM. ${ }^{67}$

Pada tahap penawaran kepada mitra ini akan ada $\mathrm{MoU}$ yang dituliskan dalam simulasi kerja sama yang sudah dibuat KM. Data simulasi tersebut menjelaskan apa saja hal yang bisa dikerjasamakan. Misalnya, kerja sama berupa membantu menangani

\footnotetext{
64 "Darmawan, "MPLS."

65 Ibid.

66 Anugrah, "Mengintip Kampung Bisnis Online DI Purbalingga."

67 Wahidatul Munawaroh, "Implementasi Pendidikan Karakter DIsiplin Beribadah Dalam Komunitas Bisnis Online Kampung Marketer Tanjungmuli Karangmoncol Purbalingga," 77-105.
}

customer service, atau konten pemasaran. Setiap pekerjaan yang ditawarkan itu memiliki biaya gaji yang berbeda, bonus berbeda, dan infrastruktur berbeda. ${ }^{68}$ Sehingga, mitra pengusaha harus menyediakan infrastruktur pemasaran dan dana sesuai yang disepakati dalam MoU. Dalam sistem kerja sama ini bisa satu SDM bekerja di satu perusahaan dan satu pekerjaan, bisa juga satu SDM bekerja untuk dua pekerjaan dari satu perusahaan UMKM, bahkan SDM bisa bekerja di beberapa perusahaan karena pekerjaanya hanya butuh sedikit waktu. Semua sistem itu perlu dirumuskan perjanjian antara KM dengan perusahaan, sehingga SDM memiliki kejelasan jam kerja, apa pekerjaannya, berapa gajinya dan bonusnya. Jika ada perusahaan yang tidak menjalankan kewajibannya dengan baik, maka KM akan bisa mengingatkan. Sebaliknya, jika perusahaan mitra tidak suka dengan SDM, bisa request untuk ganti. ${ }^{69}$ Oleh karena itu, ketika ada persoalan SDM yang tidak bisa bekerja karena merawat orang tua, sakit, maka KM akan membantu mendampingi menyampaikan ke perusahaan mitra. ${ }^{70}$

\section{Aset Komunitas pada Kampung Marketer}

Aset komunitas adalah sumber daya yang dimiliki oleh masyarakat dan digunakan dalam kegiatan pemberdayaan. ${ }^{71}$ Aset komunitas dapat dipetakan dari beberapa proses pemberdayaan yang dilalukan oleh

\footnotetext{
68 Kampung Marketer, "Simulasi Pemberdayaan SDM Kampung Marketer," Kampung Marketer, March 27, 2021, https://kampungmarketer.com/.

69. Darmawan, "Leader Talk."

$70 \mathrm{lbid}$.

${ }^{71}$ Djawahir, "Asset Based Community Development Di Pesantren Wisata: Implementasi Strategis Di PP. AnNur 2 Al Murtadlo Malang," 23-34.
} 
KM. Aset ini dapat di identifikasi dari sumber daya yang digunakan oleh subjek pemberdaya dan objek pemberdayaan dalam menjalankan kegiatan produktifnya.

\section{Aset Manusia}

Aset manusia adalah manusia dengan segala aspek pengetahuan, keterampilan, kepandaian, dan pengalamannya, yang diposisikan sebagai sumber daya yang bergerak dengan melakukan suatu kegiatan pemberdayaan untuk memperoleh manfaat sosial. ${ }^{72}$ Aset manusia pada pemberdayaan Kampung Marketer adalah pemuda desa.

Pemuda desa Tamansari Purbalingga. Pemuda desa yang mau mendaftarkan diri bergabung dengan KM, mau mengikuti pelatihan $\mathrm{KM}$, dan mau memiliki pekerjaan atas skill yang didapatkan dari KM. ${ }^{73}$ Start awal pemuda desa yang direkrut adalah pemuda yang sebelumnya tidak memiliki kemampuan teknologi bahkan pemuda yang tidak mengerti laptop, internet, dan digital marketing sama sekali. Namun, mereka memiliki semangat untuk belajar dan memperbaiki kehidupan ekonominya. Awalnya, hanya sedikit pemuda yang berminat untuk menyatakan bergabung, awalnya dua orang, kemudian menjadi banyak pemuda yang bergabung dan dilatih. ${ }^{74}$ Pemuda yang bergabung ada yang laki-laki dan perempuan. Usianya antara 17 tahun hingga 30 tahun. Latar belakang pendidikan pemuda tersebut ada yang SMP, SMA, dan SMK. Secara latar belakang pekerjaannya ada yang sebelumnya menetap di desa, ada yang sudah merantau

\footnotetext{
72 Usman, Modal Sosial, 2-4.

73 Darmawan, "Leader Talk."

74 Darmawan, "MPLS."

75 Wicaksono, "Nofi Bayu Darmawan, Mendorong Anak Muda Melek Teknologi."
}

ke ibukota untuk bekerja lalu kembali ke desa. ${ }^{75}$ Kriteria pemuda yang diutamakan untuk diberdayakan adalah pemuda yang tidak pemalu, komunikatif, tidak melankolis, kreatif, dan inovatif. Sehingga mereka akan mampu untuk diajak berlatih ecommerce. ${ }^{76}$

Dari sudut pandang ekonomi, pemuda desa ini tentunya tidak menuntut gaji yang tinggi karena UMK di desa ini kecil, karena wilayahnya di kabupaten. Akan berbeda dengan pemuda kota yang memiliki tuntutan gaji tinggi mengikuti UMK kotanya. ${ }^{77}$ Secara etos kerja, pemuda ini dapat mengikuti pelatihan dan pemberdayaan KM dengan baik, karena jika tidak mereka tidak akan bertahan di KM. ${ }^{78}$

\section{Aset Fisik}

Aset fisik adalah sumber daya infrastruktur yang digunakan dalam kegiatan pemberdayaan. Infrastruktur ini sangat dibutuhkan, karena menjadi peralatan utama atau bahan baku dalam kegiatan pemberdayaan. ${ }^{79}$ Aset fisik yang digunakan pada kegiatan ini berupa rumah Nofi Bayu, rumah warga pijaman dan yang berhasil disewa, serta balai desa. Berikut rincian aset fisik pada kegiatan pemberdayaan oleh KM.

Pertama, rumah orangtua Nofi Bayu. Rumah berukuran $10 \times 6,5$ meter. Rumah ini dilengkapi dengan perangkat komputer. Di rumah tersebut juga dilengkapi dengan berbagai kata mutiara untuk penyemangat dan doa, antara lain: "Wong Ndeso, Rezeki Kutho, "Action Gila - gilaan", "Stop Nyinyir, Start Nyambut Gawe!", "Sudahkah

\footnotetext{
${ }^{76} \mathrm{lbid}$.

77 Darmawan, "Leader Talk."

78 Hendrik, interview.

79 Usman, Modal Sosial, 2-4.
} 
Bermanfaat Bagi orang lain", "Nyari Duit Gak Harus Ke Kota". ${ }^{80}$ Rumah ini gratis dapat digunakan untuk kegiatan KM, dan memiliki luas yang cukup untuk kegiatan KM dengan jumlah anggota masih sedikit.

Kedua, rumah warga desa. Rumah yang dipinjamkan ke KM oleh salah satu warga ditahun awal, dan rumah yang disewa oleh KM. Awalnya rumah tersebut adalah rumah desa yang sederhana, namun kemudian diubah menjadi rumah dengan teknologi canggih karena dilengkapi menara penguat sinyal internet. ${ }^{81}$ Rumah tersebut dilengkapi komputer atau laptop, listrik, ponsel, meja, kursi, dan alat lainnya. Di tahun pertama, mendapatkan bantuan rumah Ibu Hilal yang digunakan untuk kantor secara gratis selama 1 tahun. Barulah setelah KM semakin maju mulai membayar sewa ditahun ke-2. Kemudian KM menyewa rumah-rumah warga lainnya juga untuk kegiatan KM karena membutuhkan banyak tempat. ${ }^{82} \mathrm{Di}$ dalam satu rumah terdapat banyak SDM. Juga terdapat tempat dengan meja, kursi peserta, laptop serta alat lainnya. ${ }^{83}$ Rumahrumah warga yang dijadikan kantor dan tempat pelatihan tersebut disewa dengan kisaran harga pertahun Rp. 3 juta-3,5 juta. Harga yang cukup murah. ${ }^{84}$ Secara keluasan rumah tersebut dapat digunakan untuk menampung banyak orang, perlengkapan meja kursi, laptop, dan parkir. Rumah dengan karakter desa yang tidak banyak bersekat namun luas. Sehingga, rumah ini menjadi layak untuk dijadikan kantor KM.

\footnotetext{
80 Wicaksono, "Nofi Bayu Darmawan, Mendorong Anak Muda Melek Teknologi."

$81 \mathrm{lbid}$.

82 Hendrik, interview.

83 Kampung Marketer, "Liputan Media Dan Penghargaan," Kampung Marketer, March 26, 2021, https://kampungmarketer.com/.
}

Jumlah rumah warga yang diberdayakan menurut informasi ketua KM tahun 2019 ialah sebanyak 26 rumah. Hal ini terjadi karena jumlah SDM yang bekerja banyak, meskipun ada beberapa SDM yang juga bekerja di rumah karena ada halangan misalkan merawat orang tua, hamil, dan sakit. Namun, tetap saja jumlah SDM yang bekerja di kantor KM masih sangat besar. ${ }^{85}$ Pembayaran sewa rumah ini dari dana internal yang dimiliki Kampung Marketer, baik dana modal dari Nofi Bayu maupun dari pemasukan biaya oleh mitra Kampung Marketer yang bargabung sesuai MoU. ${ }^{86}$

Ketiga, balai desa. Balai desa yang ada di desa, yang biasanya menjadi tempat kumpul-kumpul warga termasuk pemuda desa yang menjadi sasaran KM. Tempat ini juga menjadi tempat kegiatan KM dalam hal memberikan informasi KM kepada pemuda desa, menyadarkan pemuda desa agar mau bergabung dengan KM. ${ }^{87}$ Balai desa ini merupakan tempat umum yang biasanya digunakan untuk kegiatan kumpul warga, misalkan kegiatan rapat kampung, atau untuk kegiatan warga uang ingin berkumpul hanya untuk ngobrol. Banyak pemuda desa yang nongkrong juga di balai desa ini dan disanalah kemudian dimanfaatkan untuk kegiatan penyadaran oleh anggota KM.

\section{Aset Sosial}

Aset sosial adalah aset berupa relasi-relasi sosial, nilai-nilai sosial, norma-norma sosial yang digunakan untuk melakukan kegiatan produktif yang dilakukan komunitas untuk

\footnotetext{
84 Wicaksono, "Nofi Bayu Darmawan, Mendorong Anak Muda Melek Teknologi."

${ }^{85}$ Marketer, "Kolaborasi Yang Berdampak."

86 lbid.

87 Hendrik, interview.
} 
memperoleh manfaat sosial. ${ }^{88}$ Pada pemberdayaan KM ini aset sosial yang diperankan adalah instansi pemerintahan khususnya pihak kecamatan, nilai sosial terkait guyub, UMKM yang berada dekat dengan desa Tamansari Kabupaten Purbalingga, sebagai mitra bisnis. Berikut rincian penjelasan aset fisik Kampung Marketer.

Pertama, Pengusaha UMKM mitra KM. Pengusaha ini merupakan jaringan rekanrekan bisnis Nofi Bayu. Perusahaan ini memiliki kebutuhan pemasaran online, mereka mau bekerja sama menjadi mitra. UMKM ini ada yang dari internal desa Purbalingga dan ada yang eksternal desa. Belum tahu pasti rincian jumlah perusahaan dari internal kabupaten saja. Namun, UMKM yang ada di kabupaten, mereka yang memiliki usaha jualan online, mereka sangat terbantu dengan adanya kerja sama dengan KM. Bentuk kerja samanya ada beragam, ada yang perusahaan UMKM meminta pemasaran online semua diserahkan ke Kampung Marketer, ada yang hanya meminta SDM untuk Customer service, atau administrasi. UMKM biasanya memberikan perlengkapan semua keperluan infrastruktur untuk dijadikan alat pemasaran kepada pihak KM dan akan digunakan SDM yang bertanggung jawab mengurusi perusahan tersebut. Jika kerja sama berhenti, maka semua perlengkapan itu dikembalikan ke mitra. Tetapi jika lanjut maka bisa dilanjutkan kerja sama. ${ }^{89}$ Perlengkapan tersebut ponsel, komputer, dan device lainnya dengan kualifikasi tertentu yang diperlukan untuk menjalankan tugas

88 Usman, Modal Sosial, 2-4.

89 Darmawan, "Leader Talk."

90 Marketer, "Simulasi Pemberdayaan SDM Kampung Marketer." pemasaran online dari Mitra. Device diberikan kepada SDM yang sudah ditunjuk menjadi SDM yang mengurusi mitra tersebut. Jika terjadi penggantian maka mitra tersebut harus menyediakan. ${ }^{90}$ Sehingga, mitra tersebut memasrahkan semua pada SDM KM yang telah ditunjuk, jika mitra kurang cocok dengan SDM ataupun gagasan yang ada dapat diganti. ${ }^{91}$ Mitra harus memberikan dana untuk bonus bahkan kegiatan refreshing SDM KM sesuai perjanjian MoU. ${ }^{92}$ Perusahaan mitra dapat melakukan monitoring pekerjaan SDM yang bekerja di kantor KM dengan mengakses software yang sudah disediakan. SDM dapat bekerja profesional dan perusahaan mitra dapat mengontrolnya. Jika ada SDM yang sakit, atau ada kendala bekerja, SDM harus ijin dan memberitahukan perkembangan ke KM dan pihak mitra perusahaan tempatnya bekerja. ${ }^{93}$

Kedua, Kepala desa pihak Kecamatan, dan Bupati yang mendukung kesuksesan kegiatan Kampung Marketer melalui jabatan mereka sebagai perangkat desa, mereka mengajak pemuda untuk bergabung dalam KM. Pihak pemerintah ini berhubungan secara formal dengan KM, bukan hubungan pribadi. ${ }^{94}$ Ketiga, nilai sosial masyarakat yakni guyub. Nilai guyub yang ada di masyarakat membuat masyarakat begitu akrab satu dengan yang lain. Misalkan, hubungan dengan tetangga, atau keluarga, mereka saling bersilaturahmi ke kerumah masing-masing, membicarakan kabar terbaru warga kampung, saling

\footnotetext{
91 Darmawan, "Leader Talk."

92 lbid.

93 "ibid."

94 Hendrik, interview.
} 
menyebarkan informasi sesuatu yang viral di desa dari mulut ke mulut secara cepat. ${ }^{95}$

\section{Aset Finansial}

Aset finansial adalah perputaran uang yang digunakan dalam kegiatan pemberdayaan, uang tidak hanya dibiarkan diam saja, tetapi digunakan untuk membiayai kegiatan. ${ }^{96}$ Aset finansial yang murni dari komunitas masyarakat dimulai saat anggota yang sudah bergabung dengan $\mathrm{KM}$, mereka kemudian mengikuti perlombaan dan hasilnya menang, sehingga hadiah berupa dana dari perlombaan yang diikuti anggota Kampung Marketer ini menjadi pemasukan dana. Hal ini yang menjadi pemasukan dana KM. Untuk modal awal dana didapatkan dari sumbangan Nofi Bayu. Kemudian dana KM juga didapatkan dari keuntungan kerjasama dengan mitra bisnis. Dana dari mitra yang telah bekerja sama dengan KM. ${ }^{97}$ Mengacu pada panduan kerjasama KM dengan mitra bisnis, mitra menyediakan dana untuk gaji SDM, bonus, dan operasional KM. Dana operasional ini yang akan masuk ke kas KM. ${ }^{98}$

\section{Peranan Aset Pada \\ Pemberdayaan Komunitas Kampung Marketer}

Peranan aset dalam pemberdayaan dapat diidentifikasi pada proses pemberdayaan yang dilakukan komunitas. Proses pemberdayaan memiliki beberapa tahapan yakni penyadaran, pelatihan, dan penguatan intelektual. Uraian studi ini terkait dengan peranan aset akan dijelaskan tentang mekanisme aset yang diperankan sesuai

\footnotetext{
95 Ibid.

${ }^{96}$ Usman, Modal Sosial, 2-4.

${ }^{97}$ Hendrik, interview.
}

dengan tahapan pemberdayaan yang dilakukan oleh KM.

\section{Tahapan Penyadaran}

Tahap penyadaran adalah tahap memberikan informasi pada pemuda agar mau bergabung dengan KM. Upaya yang dilakukan KM mulai dari menawari kerabat subjek penggerak KM, pemuda desa di balai desa, menyebarkan kesuksesan KM melalui mulut ke mulut, dan spanduk yang dipasang di kantor KM. Pada tahap ini, aset yang diperankan, aset manusia yakni pemuda desa. Pemuda desa yang yang menjadi objek sasaran diberikan kesadaran akan pentingnya skill digital marketing. Pemuda desa yang tergabung terklasifikasi menjadi anggota awal yakni dua pemuda yang merupakan saudara Nofi Bayu, kemudian Pemuda desa yang bergabung pada babak ke- 2,3, dst. Dua pemuda desa yang berhasil disadarkan kemudian menjadi subjek yang ikut menyadarkan pemuda lain bersama Nofi Bayu untuk babak ke- 2. Kemudian berputar lagi, pemuda yang sudah ikut di babak ke 2 juga ikut menyadarkan pemuda lain agar bergabung pada babak ke 3, berputar pada babak ke 4. Mereka awalnya menjadi objek kemudian menjadi subjek dalam kegiatan pemberdayaan. Bahkan sebagai subjek, mereka juga akan menjadi pengelola organisasi KM. Organisasi yang menjadi wadah kegiatan pemberdayaan ini. sehingga aset manusia dalam tahap ini dapat diperankan sebagai objek, kemudian sebagai subjek yang aktif melakukan kegiatan penyadaran.

Peranan Aset fisik. Aset yang diperankan awalnya adalah rumah orang tua Nofi Bayu.

98 Marketer, "Simulasi Pemberdayaan SDM Kampung Marketer." 
Rumah sebagai tempat diskusi awal kali menyadarkan dua pemuda untuk bergabung. Kemudian pada tahap berikutnya kegiatan penyadaran ini dilakukan di balai desa. Karena balai desa menjadi tempat nongkrong pemuda desa, disinilah Nofi Bayu memberikan informasi tentang pentingnya skill digital marketing kepada banyak pemuda di babak ke-2. Peranan aset fisik Balai desa sebagai tempat interaksi antara Nofi dan dua anggota KM dengan para pemuda untuk menyampaikan informasi ide atau gagasan pemberdayaan. Tempatnya yang luas, maka bebas digunakan untuk aktivitas publik, termasuk aktifivitas KM. Setelah banyak pemuda yang mau bergabung, dan sukses, KM menjadi terkenal, untuk tahap penyadaran melalui menempelkan spanduk dirumah-rumah desa yang berhasil dipinjamkan dan disewa menjadi kantor pusat kegiatan KM. Aset fisik yang diperankan adalah rumah-rumah desa. Ada perubahan aset fisik yang diperankan, menyesuaikan dengan kemampuan KM memiliki tempat tersebut dan efektivitas promosi yang dapat dilakukan. Aset fisik diperankan sebagai tempat melakukan kegiatan penyadaran ke pemuda desa.

Peranan Aset sosial. Jaringan sosial juga dilibatkan dalam pemberdayaan ini. Peranan kepala desa, camat, dan bupati sangat penting dalam memberikan dukungan untuk kesuksesan KM dalam memberikan informasi penyadaran ke masyarakat akan pentingnya digital marketing. Pemerintah setempat memberikan ijin untuk komunitas terus memberi kesadaran digital marketing ke pemuda desa di balai desa. ${ }^{99}$ Ketika KM semakin sukses karena sudah mulai banyak yang terbukti bisa mengikuti kegiatan

${ }^{99}$ Hendrik, interview.

100 lbid. pelatihan dan mendapatkan pekerjaan, pihak Kecamatan dan Bupati juga mendukung kegiatan ini dengan diajak diskusi di Pendopo untuk dibantu bagaimana cara supaya KM semakin sukses dan lalu membantu sosialisasi ke masyarakat. ${ }^{100}$ Dukungan ini menjadi peluang untuk KM dapat diterima oleh masyarakat. Masyarakat semakin banyak yang mengenal $K M$, semakin percaya dengan $\mathrm{KM}$, dan antusias pendaftar anggota KM semakin banyak.

Peranan aset sosial. Nilai-nilai guyub yang menjadi pijakan berperilaku masyarakat. ${ }^{101}$ Masyarakat di desa ini memiliki nilai guyub akhirnya membuat masyarakat sering berkumpul antar warga, saudara, dan teman. Pertemuan itu biasanya membicarakan masalah desa, termasuk informasi kesuksesan KM. Ketika ada anggota yang sukses, maka tetangganya akan membicarakannya, kemudian dari mulut ke mulut akan tersebar dengan cepat. Peranan aset sosial ini sebagai pendukung, pemercepat, dan penguat untuk KM diketahui dan diterima oleh pemuda desa, mungkin karena masyarakat akan yakin pada organisasi yang jelas formalitasnya dan yang sedang viral dimasyarakat.

Aset finansial yang digunakan. Aset finansial awal belum ada dana komunitas, masih dana pribadi Nofi Bayu. Ketika sudah memiliki organisasi KM, barulah mereka menggunakan dana kas organisasi yang didapatkan dari lomba pengurus dan kerjasama dengan mitra bisnis. Dana itu untuk pengadaan spanduk, menyewa rumah-rumah untuk kantor, membeli peralatan internet, dan kebutuhan operasional lainnya. Peranan dana sebagai

101 Ibid. 
biaya yang penggunaannya menyesuaikan dengan bentuk kegiatan penyadaran yang dilakukan. Dana mempengaruhi strategi penyadaran ke masyarakat, saat dana sedikit maka kegiatan yang dilakukan harus yang memerlukan biaya seminimal mungkin misalkan penyadaran di balai desa tempat gratis, namun ketika sudah banyak dana akan berbeda caranya misalnya dengan spanduk dengan jumlah banyak tentunya dengan biaya tertentu.

\section{Tahap Pelatihan}

Tahap pelatihan adalah memberikan daya kepada objek pemberdaya. Pada tahap ini KM memberikan pelatihan digital marketing dan pelatihan menjadi SDM yang baik. Tahap ini aset yang diperankan Aset manusia yakni Pemuda desa. Awalnya, Pemuda bergabung dalam Kampung Marketer sebagai objek yang akan diberikan pelatihan. Babak pelatihan ini dapat diklasifikasi dalam beberapa babak; (1) pelatihan dua orang pemula pemuda ini menjadi percontohan bagi pemuda lain di desa bahwa skill digital marketing bisa dipelajari dan dimiliki; (2) pelatihan babak ke- 2,3, dst. Kondisi awal semua pemuda yang baru ikut pelatihan sama, yakni tidak memiliki pengetahuan prospektus digital marketing, apalagi skill digital marketing. Kegiatan pelatihan terkurikulum dalam waktu tertentu. Untuk periode awal pelatihan ini dilatih Nofi Bayu langsung selaku agen pemberdayaan, namun setelah semakin banyak pemuda yang sudah ikut pelatihan, sudah memiliki skill maka banyak pemuda yang sudah menguasai skill digital marketing. Melihat kelas pelatihan juga semakin banyak, maka subjek pelatih adalah pemuda yang sudah mengikuti pelatihan dan unggul. Peranan aset manusia dalam tahap ini adalah sebagai objek dan subjek pemberdayaan. Ketika
SDM belum memiliki skill maka menjadi objek, tetapi ketika sudah memiliki skill dan unggul maka akan berubah menjadi subjek pelatih, mengingat kebutuhan kegiatan pelatihan ini yang semakin banyak diadakan oleh KM.

Peranan Aset fisik. Rumah orang tua Nofi Bayu sang pelopor Kampung Marketer, rumah ini digunakan pelatihan awal dan saat anggota yang bergabung jumlahnya masih sedikit. Namun, ketika jumlahnya sudah ratusan, maka kegiatan pelatihan menggunakan rumah warga yang dipinjamkan. Setelah semakin banyak yang ingin mengikuti pelatihan, KM pun menyewa rumah warga dari dana yang dimiliki. Rumah-rumah yang digunakan dilengkapi dengan menara internet serta berbagai device untuk kebutuhan online, dilengkapi juga dengan perlengkapan seperti komputer, meja, kursi. Peranan aset fisik berupa rumah dengan berbagai pelengkapan internetnya digunakan sebagai tempat untuk menjalankan kegiatan pelatihan, dimulai dari satu rumah menampung sedikit anggota, hingga beberapa rumah menyesuaikan dengan jumlah anggota yang dilatih dan dana yang ada. Ketika semakin banyak yang dilatih, maka aset fisik tempat pelatihan yang diadakan juga semakin banyak.

Peranan Aset finansial. Dana yang dimiliki KM pada tahap ini diperankan sebagai pembiayaan operasional, mulai dari pembelian berbagai device, sarana internet, meja kursi, dan keperluan lainnya. Saat tahun pertama, tidak banyak pengeluaran karena hanya sedikit anggota yang mengikuti pelatihan dan menggunakan rumah Nofi, namun pada tahun berikutnya hingga sekarang, pelatihan dilakukan untuk 
banyak pemuda, sehingga semakin banyak pula kebutuhan biayanya karena semakin banyak rumah untuk pelatihan, manara internet, meja kursi, komputer, dan lainnya. Asumsinya pelatihan gratis, maka biaya seluruhnya ditanggung KM. Maka peranan aset finansial adalah sebagai dana yang membiayai seluruh kebutuhan pelatihan. Saat anggota pelatihan semakin besar, membutuhkan tempat yang banyak, device dan perangkat internet yang banyak, maka biaya yang diperankan juga semakin besar.

\section{Tahap Peningkatan Intelektual}

Tahap ini, adalah tahap objek pemberdayaan untuk meningkatkan ekonominya secara mandiri. Dalam pemberdayaan KM, pemuda desa menjadi SDM yang bekerjasama dengan mitra bisnis UMKM atau mendirikan usaha sendiri yang berkaitan dengan pemasaran online. Aset yang diperankan dalam tahap ini adalah aset manusia. Pemuda desa yang sudah mendapatkan pelatihan, baik saat babak 1,2,3, dst diberikan kebebasan memilih pekerjaan. Untuk Pemuda desa yang memilih menjadi SDM, mereka yang memiliki kelebihan yang tidak dimiliki pemuda kota, yakni gaji untuk mereka lebih murah, mereka yang memiliki etos kerja baik, mereka yang juga memiliki skill spesialis digital marketing yang sudah dilatihkan oleh KM, maka mereka sebagai objek SDM upaya pemberdayaan KM. Pemuda yang bekerja juga memiliki pembagian peran sebagai manajemen organisasi KM. Aset manusia dalam tahap ini berperan sebagai subjek pengelola organisasi KM sekaligus objek sebagai SDM KM.

Peranan aset fisik. Rumah orang tua Nofi Bayu, rumah yang berhasil disewa, dan rumah yang dipinjami warga. Saat periode awal, pemuda yang berhasil diberdayakan menjalankan pekerjaan sebagai pemasar online suatu perusahaan di rumah orang tua Nofi Bayu. Kemudian, menggunakan juga rumah hasil pinjaman untuk kantor kerja SDM yang bergabung dengan KM. Saat ini, rumah banyak digunakan untuk kegiatan koordinasi anggota KM, kantor kerja SDM, komunikasi dengan mitra bisnis jumlahnya ada 26 rumah. Rumah yang ada di desa sangat sesuai dengan kebutuhan KM yang membutuhkan ruangan luas, parkir luas, dan harga murah sehingga bisa menampung banyak anggota dan sesuai kondisi keuangan KM. Rumah ini memengaruhi harga jual jasa SDM di KM menjadi murah. Sehingga, peranan aset fisik rumah adalah sebagai kantor pusat kegiatan KM tahap kemandirian ekonomi.

Peranan aset sosial. Mitra bisnis yang berhasil bekerja sama memberikan tempat bekerja SDM KM, dan mereka juga mendapat keuntungan balik, usaha online mereka dapat dijalankan dengan baik karena dibantu SDM ahli dari KM. Peranan mitra ini sangat penting untuk mendukung kegiatan KM ini bisa berjalan, karena tanpa mitra bisnis tidak akan ada tahap SDM mandiri secara ekonomi, KM tidak akan menarik lagi bagi pemuda, pemberdayaan akan terhenti, tidak akan ada perputaran dana.

Aset sosial nilai guyub. Nilai guyub khas masyarakat desa yang membuat masyarakat mendukung kegiatan $\mathrm{KM}$, tidak memberikan penolakan terhadap program-program KM, atau upaya tertentu yang menghambat 
kegiatan Kampung Marketer. ${ }^{102}$ Misalkan, kegiatan KM di tengah kampung seringkali membuat keramaian, namun masyarakat merasa tidak enak jika menegur, akhirnya memaafkan dengan mudah. Tidak ada pertentangan yang berarti karena tetangga mudah memaafkan sebagai sesama warga desa, meskipun ada sedikit rasa kesal. Peranan nilai sosial masyarakat dalam tahap ini adalah melancarkan kegiatan KM tanpa hambatan dari masyarakat akibat gangguan yang dimunculkan oleh anggota KM.

Peranan aset finansial. Pada tahap ini dana digunakan untuk memberi gaji SDM, dan operasional organisasi KM. Dana yang masuk menjadi kas KM, baik dari mitra bisnis dan hasil lomba ini membuat organisasi KM bisa berputar terus. Jumlah mitra bisnis yang banyak, memberikan pemasukan dana yang besar bagi KM, maka Anggota KM yang bisa bekerja, mendapatkan gaji, dan menjalankan peran mengelola organisasi KM pun jumlahnya semakin banyak. Sehingga, pemuda desa yang berhasil berdaya secara ekonomi pun semakin banyak. Aset dana dalam tahap ini diperankan sebagai biaya gaji, bonus, dan sewa rumah untuk kantor KM yang tentunya dengan berbagai perangkatnya.

\section{Kesimpulan}

Pemberdayaan berupa memberikan skill digital marketing dan memberikan pekerjaan sebagai SDM marketer online telah sukses dilakukan Kampung Marketer. Pemberdayaan yang dilakukan Kampung Marketer ini memerankan beberapa aset. Aset manusia, pemuda desa berperan menjadi objek sasaran sekaligus sebagai agen atau subjek yang mengembangkan kegiatan pemberdayaan di desa. Sebagai objek mereka akan mengikuti semua kegiatan penyadaran, pelatihaan, dan bekerja. Pemuda yang bergabung ini juga berperan aktif sebagai subjek baik ikut menyadarkan pemuda lain, membentuk organisasi KM dan maupun sebagai SDM pelatih di KM. kegiatan pemberdayaan KM bisa berjalan sesuai tahapan karena peran aktif aset manusianya. Aset manusia inilah yang merealisasikan semua upaya untuk mencapai tujuan pemberdayaan KM, yakni memberikan pelatihan skill digital marketing untuk pemuda desa agar mereka dapat berdaya secara ekonomi.

Aset fisik yang diperankan dalam pemberdayaan ini adalah rumah orangtua Nofi, rumah-rumah warga desa. Aset fisik ini sebagai tempat kegiatan KM, baik untuk penyadaran, pelatihan, kantor, dan koordinasi komunitas KM. Rumah desa yang luas dan murah sangat cocok untuk KM. Kemudian, aset fisik berupa Balai Desa, tempat umum yang diperankan sebagai tempat sosialiasi program KM kepada pemuda desa pada saat tahap awal, tempat ini menjadi lumbung pasar yang prospek untuk melakukan penyadaran. Tempat yang gratis dan berisi banyak pemuda desa berkumpul. Aset fisik ini sebagai tempat pusat kegiatan KM, tempat yang luas, kondusif dan murah membuat KM bisa menjalankan semua kegiatannya ditengah kondisi dana yang juga masih proses ditingkatkan.

Aset sosial yang diperankan adalah dukungan kepala desa, camat, dan bupati membuat KM mendapatkan perijinan

102 Ibid. 
menggunakan balai desa sebagai tempat penyadaran, dan dukungan berupa sosialisasi pemerintah tentang KM membuat KM mendapatkan kepercayaan masyarakat. Aset Nilai guyub berupa kebiasaan saling bersilaturahmi antar warga, juga mendukung kesuksesan kegiatan pemberdayaan KM dalam hal mempercepat pengenalan masyarakat pada KM melalui informasi mulut ke mulut. Nilai guyub ini juga membuat masyarakat lebih bisa menerima kegiatan KM di tengah-tengah masyarakat. Aset jaringan pengusaha UMKM yang memberikan lahan pekerjaan untuk SDM dari KM, sehingga bekerja bisa mendapatkan gaji yang membuat anggota KM berdaya secara ekonomi, dan membuat organisasi KM bisa berputar terus menjalankan kegiatan penyadaran, pelatihan, pemberian kerja SDM. Aset sosial khususnya dukungan pemerintah dan nilai guyu masyarakat dapat mendukung, mempermudah, mempercepat KM dalam semua kegiatannya yang sebelumnya dianggap asing dan negative. Sedangkan mitra bisnis dapat mendukung dana dan memberikan daya kemandirian ekonomi pemuda desa, dengan demikian kegiatan pemberdayaan menjadi berjalan.

Aset finansial berupa hasil lomba anggota KM dan pemasukan dari mitra bisnis KM diperankan sebagai biaya dalam semua kegiatan KM. Seluruh kebutuhan KM untuk pengadaan rumah sekaligus perlengkapan jaringan internet, komputer, $L C D$, dan berbagai device yang dibutuhkan dapat dipenuhi. Dana mempengaruhi KM bisa menyewa rumah yang banyak untuk pusat kegiatannya, dan terus memberikan pelatihan gratis untuk pemuda lainnya.

Studi ini, memberikan contoh bagi praktisi yang ingin melakukan kegiatan dakwah bil hal kepada pemuda desa, melalui pemberdayaan, dengan memanfaatkan aset yang dimiliki masyarakat, serta memanfaatkan peluang teknologi pada masa modern ini. Studi ini, juga memberikan pengetahuan terkait peranan aset komunitas, dalam suatu kegiatan dakwah bil hal yang berbentuk kegiatan pemberdayaan.

\section{Bibliografi}

Adhiana. "Analisis Identifikasi Pemilikan Aset Petani Pasca Tsunami Di Aceh." Agrifo: Jurnal Agribisnis Universitas Malikussaleh 2, no. 2 (2017): 34-49. doi.org/10.29103/ag.v2i2.367. Aira, Aras. "Peran Manajemen Aset Dalam Pembangunan Daerah." Kutubkhanah 17, no. 1 (2015): 21-39. http://ejournal.uinsuska.ac.id/index.php/Kutubkhanah/article/download/807/767.

Aliyudin. "Dakwah Bi Al-Hal Melalui Pemberdayaan Ekonomi Masyarakat." Anida Aktualisasi Nuansa Ilmu Dakwah 15, no. 2 (2016): 187-206. https://doi.org/10.15575/anida.v15i2. Ansori, Teguh. "Revitalisasi Dakwah Sebagai Paradigma Pemberdayaan Masyarakat." Jurnal Dakwah Dan Sosial 2, no. 1 (2019): 33-44. https://doi.org/10.5281/zenodo.3544714. Anugrah, Arbi. "Mengintip Kampung Bisnis Online DI Purbalingga." Detikinet, March 13, 2018. https://inet.detik.com/cyberlife/d-3906135/mengintip-kampung-bisnis-online-dipurbalingga.

Chasanah, Nur. "Implementasi Knowledge Management Dengan Pendekatan Soft System 
Methodology (Studi Kasus: Kampung Marketer, Purbalingga)." In Prosiding Nasional Rekayasa Teknologi Industri Dan Informasi XIII, 142-48, 2018. https://journal.itny.ac.id/index.php/ReTII/article/view/1089.

Christoper, Dereau. "Pembaru Dan Kekuatan Lokal Untuk Pembangunan." TT: Australian Community Development and Civil Society Strengthening Scheme (ACCESS), 2013. Departemen Agama, RI. Al-Qur'an Terjemahan. Semarang: CV. Toha Putra, 1989.

Djawahir, Abdillah Ubaidi. "Asset Based Community Development Di Pesantren Wisata: Implementasi Strategis Di PP. An-Nur 2 Al Murtadlo Malang." At-Tamkin: Jurnal Pengabdian Kepada Masyarakat 1, no. 1 (2018): 23-34. https://doi.org/10.33379/attamkin.v1i1.95.

Fedryansyah, Muhammad, and Risna Resnawaty. "Penganggulangan Kemiskinan Melalui Pengembangan Aset Komunitas." Share: Social Work Journal 7, no. 1 (2017): 124-29. doi.org/10.24198/share.v7i1.13828.

Fianingsih. "Pemberdayaan Masyarakat Melalui Kampung Marketer - Studi Kasus Desa Tamansari Kecamatan Karangmoncol Kabupaten Purbalingga." Institut Agama Islam Negeri Purwokerto, 2020.

Fujiani, Erna Dede, Yus Darusman, and Lesi Oktiwanti. "Pemberdayaan Perempuan Kepala Keluarga (PEKKA) Melalui Pelatihan Berwirausaha." Indonesian Journal of Adult and Community Education 1, no. 1 (2019): 20-25. https://ejournal.upi.edu/index.php/IJACE/article/view/20002.

Haris, Andi Muhammad Arif. "Pengembangan Masyarakat Miskin Melalui Pemanfaatan Aset Komunitas Di Kabupaten Bandung Barat." Jurnal Mimbar Kesejahteraan Sosial 2, no. 2 (2019): 56-66. http://journal.uinalauddin.ac.id/index.php/jmks/article/view/10981/7210.

IImi, Syaiful. “Konsep Pengentasan Kemiskinan Perspektif Islam." Jurnal Al-Maslahah 13, no. 1 (2017): 67-84. doi.org/10.24260/almaslahah.v13i1.918.

Khatibah. "Penelitian Kepustakaan." Iqra': Jurnal Perpustakaan Dan Informasi 5, no. 01 (2011): 36-39. http://repository.uinsu.ac.id/id/eprint/640.

Mahmud, Imam, Mahendra Wijaya, and Drajat Tri Kartono. "Bonding, Bridging, And Linking Social Capital In Empowering Youth In Kampung Marketer, Indonesia." International Journal of Education and Social Science Research 3, no. 05 (2020): 99-108. doi.org/10.37500/IJESSR.2020.3508.

Mahmud, Imam, Mahendra Wijaya, and Drajat Tri Kartono Kartono. “Kampung Marketer Sebagai Pemberdayaan Masyarakat Melalui Pendidikan Online Marketing Di Era Revolusi Industri 4.0 (Studi Kasus Desa Tamansari, Karangmoncol, Purbalingga)." In Prosiding Seminar Nasional IImu Sosial Dan Politik: Media Baru Dan Wajah Masyarakat Pasca Revolusi Industri 4.0, Universitas Sebelas Maret. UNS (Sebelas Maret University), 2019. https://digilib.uns.ac.id/dokumen/detail/66891/Kampung-Marketer-sebagaiPemberdayaan-Masyarakat-melalui-Pendidikan-Online-Marketing-di-Era-RevolusiIndustri-40-Studi-Kasus-Desa-Tamansari-Karangmoncol-Purbalingga.

Mahmuda, Mardan. "Dakwah Dan Pemberdayaan." Al-Hikmah: Jurnal Dakwah Dan IImu Komunikasi 7, no. 1 (2020): 9-20. https://ejournal.uinib.ac.id/jurnal/index.php/alhikmah/article/view/1470. 
Marketer, Kampung. "Kolaborasi Yang Berdampak." Kampung Marketer, March 27, 2021. https://kampungmarketer.com/.

_-- . "Liputan Media Dan Penghargaan." Kampung Marketer, March 26, 2021. https://kampungmarketer.com/.

- - - "Simulasi Pemberdayaan SDM Kampung Marketer." Kampung Marketer, March 27, 2021. https://kampungmarketer.com/.

Mawasti, Wahanani, and Fasha Umh Rizky. "Peranan Aset Komunitas Dalam Pengembangan Masyarakat Islam Pada Bank Sampah Songolikoer." INTELEKSIA-Jurnal Pengembangan Ilmu Dakwah 2, no. 01 (2020): 27-54.

http://inteleksia.stidalhadid.ac.id/index.php/inteleksia/article/view/83.

McKnight, John L, and Cormac Russell. "The Four Essential Elements of an Asset-Based Community Development Process." What Is Distinctive about Asset-Based Community Process 15 (2018).

Mulyawan, Rahman. Masyarakat, Wilayah, Dan Pembangunan. Bandung: UNPAD [Universitas Padjadjaran] Press. Tersedia Secara Online Juga Di: Http://Pustaka. Unpad. Ac. Id/WpContent/Uploads/2016/10/04-Buku-OK_opt. Pdf [Diakses Di Lembang, Jawa Barat, Indonesia: 9 Oktober 2018]. Bandung: UNPAD press, 2016.

Nafi, Muhammad. “Kampung Marketer, Markas Para Pemasar," March 13, 2021. https://desa.lokadata.id/artikel/kampung-marketer-markas-para-pemasar.

Purwastuty, Ida. "Pemberdayaan Keluarga Miskin Melalui Aset Komunitas." Jurnal Mimbar Kesejahteraan Sosial 1, no. 1 (2018): 1-14. http://journal.uinalauddin.ac.id/index.php/jmks/article/download/7009/5788.

Rahman, Nuril Endi. "Pengaruh Potret Pemberdayaan Masyarakat Berbasis Aset Lokal Pada Kelompok Budidaya Ikan Koi Di Desa Banyuglugur Kecamatan Banyuglugur Situbondo." Jurnal Penelitian Kesejahteraan Sosial 17, no. 3 (2018): 207-16. http://ejournal.kemensos.go.id/index.php/jpks/article/view/1457.

Rochman, Noor. "Model Pengembangan Desa Wisata Berbasis Pemberdayaan Masyarakat." Jurnal Equilibria Pendidikan 1, no. 1 (2016): 59-69. doi.org/10.26877/ep.v1i1.1831.

Sagir, Akhmad. "Dakwah Bil-Hal: Prospek Dan Tantangan Da'i." Alhadharah Jurnal IImu Dakwah 14, no. 27 (2015): 15-27. https://dx.doi.org/10.18592/alhadharah.v14i27.1224. Usman, Sunyoto. Modal Sosial. Yogyakarta: Pustaka Pelajar, 2018.

Wahidatul Munawaroh, Riris. "Implementasi Pendidikan Karakter DIsiplin Beribadah Dalam Komunitas Bisnis Online Kampung Marketer Tanjungmuli Karangmoncol Purbalingga." Institut Agama Islam Negeri Purwokerto, 2020. http://repository.iainpurwokerto.ac.id/id/eprint/7312.

Wicaksono, Megandika. "Nofi Bayu Darmawan, Mendorong Anak Muda Melek Teknologi," March 26, 2021. https://www.kompas.id/baca/sosok/2018/03/23/nofi-bayu-darmawanmendorong-anak-muda-melek-teknologi.

Zubaedi. Pengembangan Masyarakat: Wacana Dan Praktik. Jakarta: Kencana Pranada Media Grup, 2013. 
Suciati

52 | INTELEKSIA - Jurnal Pengembangan Ilmu Dakwah 